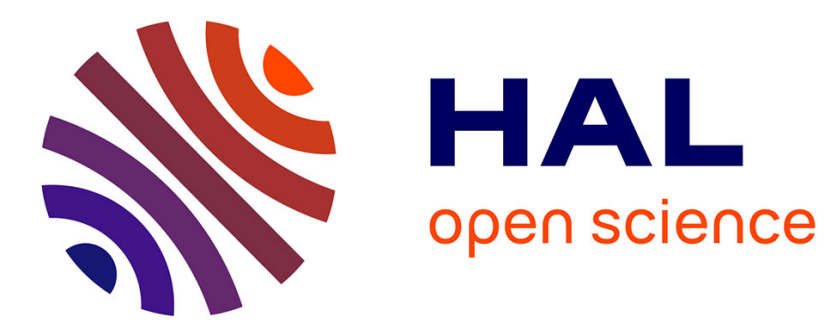

\title{
Archaeology, writing tablets and literacy in Roman Britain
}

John Pearce

\section{To cite this version:}

John Pearce. Archaeology, writing tablets and literacy in Roman Britain. Gallia - Archéologie de la France antique, 2004, L'écriture dans la société gallo-romaine, 61, pp.43-51. 10.3406/galia.2004.3186 . hal-01910937

\section{HAL Id: hal-01910937 \\ https://hal.science/hal-01910937}

Submitted on 29 Jan 2020

HAL is a multi-disciplinary open access archive for the deposit and dissemination of scientific research documents, whether they are published or not. The documents may come from teaching and research institutions in France or abroad, or from public or private research centers.
L'archive ouverte pluridisciplinaire HAL, est destinée au dépôt et à la diffusion de documents scientifiques de niveau recherche, publiés ou non, émanant des établissements d'enseignement et de recherche français ou étrangers, des laboratoires publics ou privés.

\section{(이) $\$$}

Distributed under a Creative Commons Attribution - NonCommercial - NoDerivatives| 4.0 


\title{
ARCHAEOLOGY, WRITING TABLETS AND LITERACY IN ROMAN BRITAIN
}

\author{
John Pearce
}

Key-words. Writing tablets, Roman Britain, Vindolanda, Carlisle, London, archaeological context.

\begin{abstract}
Discoveries of uniting tablets from Roman Britain, in particular of the Vindolanda uriting tablets, have revolutionized analysis of the use of documents among individual communities in the province. The insights gained from the study of the texts may be developed by further study of the archaeological contexts in which writing tablets have been found. The bras in the distribution to military sites and London is not surprising, since higher levels of literay might be anticipated. However the distribution also suggests a wider use of documents in rural contexts than has hitherto been proposed. Detailed analysis of depositional processes also promises to assist the interpretation of individual groups of documents and the investigation of the organization of archives, but significant obstacles to such analyses must be acknowledged.
\end{abstract}

Mots-clés. Tablettes à écrire, Bretagne romaine, Vindolanda, Carlisle, Londres, contexte archéologique.

Résumé. La découverte des tablettes à écrire dans des sites britto-romains, surtout à Vindolanda, a révolutionné l'étude de l'utilisation de l'écrit dans les diverses communautés de la province. Les premières observations tirées de l'étude des textes peuvent être approfondies har l'analyse des contextes archéologiques où l'on a trouvé des tablettes. La prédominance, dans leur distribution, des sites militaires e) de Londres n'est pas surprenante, du fait que l'on s'attend à un niveau d'alphabétisation plus élevé dans ces contextes. Cependant répartition indique aussi un emploi de l'écrit en contexte rural, et cela de façon plus intense qu'on ne le supposait jusqu'ici. L'analyse ninutieuse des processus de stratification parâ̂t pouvoir aider à l'interprétation des différents groupes de documents écrits, ainsi qu'à l'tude de l'organisation des archives, mais on doit reconnaître aussi l'existence d'obstacles imporlants à ce genre d'analyses.

Schlagwörter. Schreibtäfelchen, römisches Britannien, Vindolanda, Carlisle, London, archäologischer Kontext.

Zusammenfassung. Die Entdeckung von Schreibtäfelchen an römischen Fundstellen in Britannien (besonders in Vindolanda) hat die Erforschung des Schriftgebrauchs in den verschiedenen Bereichen dieser Provinz regelrecht revolutioniert. Die aus der Untersuchung der Texte gewonnenen ersten Beobachtungen lassen sich durch eine Analyse des archäologischen Kontexts vertiefen, aus dem die Funde stammen. Es ist nicht verwunderlich, daß sie hauptsächlich an Militärplätzen und in London verbreitet sind, denn an diesen Orten ist von einer stärkeren Alphabetisierung auszugehen. Allerdings belegt ihre weitere Verbreitung auch Schriftgebrauch im ländlichen Bereich, und zwar deutlicher als man dies bisher vermutet hat. Eine detaillierte Untersuchung zur Feinchronologie dürfte für die Interpretation der verschiedenenen Gruppen von Schriftdokumenten und für das Verständnis der Organisation der Archive hilfreich sein. Man muß sich aber auch über große Hindernisse im Klaren sein, die einer solchen Vorgehensweise im Wege stehen.

Übersetzung : Stefan WIRTH

The excavation of large numbers of wooden writing tablets at Vindolanda has changed radically our view of literacy and the use of documents in Roman Britain and beyond. Their discovery, as well as that of assemblages of lead 'curse tablets', have made Britannia the most prolific source of Latin documents in the western empire. The Vindolanda tablets have obliged us to acknowledge the importance of the ink writing tablet, previously a historical footnote, as a documentary medium and have allowed the detailed investigation of the habits of literacy in a single military community. Approaches to the Vindolanda tablets and to other documents have however been predominantly text-oriented. It is the argument of this article that we may gain further insights into both the literacy of the province and the interpretation of individual groups of texts from the study of the archaeological context in which wooden tablets and analogous documents have been found.

Archaeological context is increasingly valued in the study of groups of documents (Bagnall, 1995, p. 52), but the nature and scope of its potential contribution remain somewhat unclear. After outlining the current characterization of literacy in Roman Britain, the article therefore discusses the general potential of this form of evidence, as well as the associated problems, drawing illustrations from other parts of the Roman world. The evidence from Roman Britain is then re-examined 
in the light of this discussion and the implications for literacy and the use of documents in the province are considered ${ }^{45}$.

\section{LITERACY IN ROMAN BRITAIN}

On direct and indirect evidence, levels of literacy in Britain seem among the lowest of any part of the Roman world. The density of inscriptions, the most easily comparable indicator, is amongst the lowest for any province (Harris, 1989, p. 268) and their distribution concentrates on military installations rather than civilian settlements (Bíró, 1975; Raybould, 1999). Examination of proxy indicators, for example the conditions associated with the spread of literacy in more recent periods, does not support a more optimistic position for the literacy of the province (Harris, 1989). The native Celtic languages spoken by the majority of the population were not written and only a small proportion of the population, outside the army, probably restricted to social elites and perhaps some inhabitants of towns, spoke Latin. Towns were few and small: there is little evidence for complex, large-scale systems of manufacture or distribution that might promote 'craft' literacy. References to education in Britain are rare (Lapidge, 1984, p. 28-29) and their context needs careful evaluation (Woolf, 1998, p. 69-71).

While this minimalist view is plausible, some reservations must however be noted. It is generally impossible to quantify the proportion of the literate population with accuracy or precision. The lack of appropriate evidence makes it impossible to apply modern definitions of literacy to the study of the ancient world ${ }^{\text {th }}$. In any case a concern with only the proportion of the literate population tends to collapse differences within the ancient world into a generalized pre-modern mode. Dependence on cross-cultural proxy indicators for literacy has a similar effect. Quantification alone is not especially informative, since scholars are increasingly sensitive to the specific ways in which literacy is mediated in individual social and cultural contexts. Comparative study shows for example that writing and reading are often combined differently: frequently, for instance, far fewer people can write than can read. Familiar document categories, such as wills, contracts or accounts, were not necessarily used in the same ways as their modern counterparts. Literate and illiterate are rarely binary opposites. Rather, competence in the written language and familiarity with production of different categories of texts vary markedly within a 'literate' group. Even where only a small proportion of the population may have been able to produce or read documents, the administrative, economic or cultural practices that

45. The paper is linked to the preparation of vol. IV of the Roman Inscriptions of Britain (RIB) series, dedicated to writing tablets on lead and wood from Roman Britain. For this volume an inventory of published and unpublished documents was compiled from a literature review and a survey of museum collections.

46. Even comparison of contemporary literacy rates is frustrated by notorious national differences in the applications of definitions, for example the UNFSCO definition of an illiterate as 'someone who cannot with understanding both read and write a short simple statement on his evervday life'. documents sustained may have had much wider significance for literate and illiterate alike (McKitterick ed., 1990; Clanchy, 1993; Bowman, Woolf, 1994). In a province like Britain, for example, the forms of domination that documents enabled and sustained will have had an impact across the population as a whole.

Rather than quantify rates of literacy, instead we might therefore separately trace the production, circulation and use of different types of documents, whilst remaining sensitive to potential inter-connections, since all manifestations of writing can be considered an aspect of Roman 'cultural style' (Woolf, 2000 , p. 875). 'Literacy' and the 'uses of documents' are therefore used in this article as shorthand for these varied aspects. In this regard, the evidence of different types of document has not yet been fully exploited. The distribution of inscriptions, which represents the distribution of the epigraphic habit rather than literacy per se, may be compared, for example, with graffiti on ceramics (Evans, 1987). These too concentrate on military and urban sites, although the biases are not so marked. In one respect Britain enjoys an abundance of evidence, in the form of recently excavated portable documents on lead and wood, including the ink tablets from the auxiliary forts at Vindolanda and Carlisle and the lead 'curse tablets' from temples at Bath (Tomlin, 1988) and Uley (Tomlin, 1993). The contents of curse tablets imply that they were commissioned and/or written by individuals of modest status and means (Tomlin, 1988; 2002). With respect to this particular document type, we should be prepared to argue for a more generous view of literacy among the civilian population in the later Roman period. The study of wooden ink and stylus tablets, the main media known from Britain for correspondence and record keeping, may provide a broader view of document use. Ink tablets were generally put to more ephemeral uses, for example letters, exercises, notes and temporary records, stylus tablets served for more formal documents such as contracts, affidavits, receipts, promissory notes, discharge documents, tax and customs records. The distinction is not absolute however, since stylus tablets could also be used for example for letters and school exercises ${ }^{47}$. Ostraka and papyri are rarely documented in Britain. The Corbridge hoard fragments represent the only known find of papyrus, while names, indications of property and numerals predominate among texts on ceramics or tiles. To the evidence of tablets themselves can be added the writing equipment used to produce them. Previous attention has been devoted to typology and classification, but the opportunity is ripe for more general distribution studies (Hanson, Conolly, 2002).

The ink tablets from Vindolanda have allowed a rich and nuanced analysis of the use of documents among the garrison in occupation between c. AD 85 and c. AD 120, although given

47. Marichal's (1992b) summary of finds of writing tablets in the western provinces now must be supplemented (Speidel, 1996, p. 20, n. 26; France, Hesnard, 1995; Reuter, 1999; Rowe, 2001). Bowman and Thomas (1983), Speidel (1996) and Fck (1998) discuss the uses of wooden writing tablets. In Britain stylus tablets bearing legal and administrative texts (e.g. RIB, II-4, 2443.2, 11, 13, 18; Tomlin, 1996) and letters $(R I B$, II-4, 2443.3, 4, 5, 6, 7, 10, 12) are known. 
that most have been excavated from deposits associated with the praetorium (see infra), our view is only partial. For present purposes three aspects merit particular attention, (1) materials and technology of tablet production, (2) the community of readers and writers and their use of documents and (3) the degree to which military life was organized through documents (Adams, 1995; à paraître, Bowman, 1991; 1994) ${ }^{48}$.

1. Analysis of a small sample shows the Vindolanda ink tablets to have been produced from birch, alder and in one instance oak (Bowman, Thomas, 1983, p. 27-28). Unlike the stylus tablets ${ }^{49}$ or papyrus, they were made from locally available woods. The manufacturing technique demanded some expertise, perhaps related to the cutting of veneers for furniture, although not all aspects of tablet production are understood ${ }^{50}$. The standard size and shape of tablets also suggest a degree of specialization in their production. However in general raw materials and technology are unlikely to have significantly constrained the availability of this documentary medium, within the garrison at least.

2. The documents were produced by and distributed to a wide range of readers and writers. Among the 250 named individuals senior officers dominate, especially Flavius Cerialis, a praefectus of the cohors IX Batavorum, but junior officers and soldiers, women, slaves and probably civilian traders are also represented. So far no native Briton is attested for certain among the correspondents, although some of the 'Celtic' names might belong to the native population. For specific document types, writers generally observed the conventions of format and layout. Although scribes were responsible for the production of some documents (for example letters by Flavius Cerialis are written in five or six hands), hundreds of individual hands are represented in the tablets. Even where documents are highly formulaic, for example leave requests and renuntia ('all present and correct' reports), they are not chits to which individuals had only to put their name but are written out in full by the individuals concerned. Handwriting ranged from calligraphic fluency

48. The ink tablets have been published by $\mathrm{A}$. Bowman and $\mathrm{D}$. Thomas in two volumes (1983 and 1994). Talulae Vindolandenses III (Tab. Vindol. III) will publish more than 270 ink tablets excavated in the $1990 \mathrm{~s}$ and further ink tablets were excavated in 2001. The 280+ stylus tablets found from the 1970 s to 1990 s have not yet been published, save for occasional readings (Birley et al., 1993; Bowman, Thomas, 1994, p. 364-365). Some of these bear ink writing on the rims. Both ink and stylus tablets are the subjects of a current programme of digital imaging (Bowman,Tomlin, à paraitre). An online version of Tab. Vindol. II, including new digital images of the ink tablets is now available (cf. http://vindolanda.csad.ox.ac.uk).

49. Stylus tablets found in Britain are almost universally made out of non-native woods and are presumed to have been imported as notebooks. Recent analysis of tablets from London shows that silver fir is the predominant source of wood (Elkins, 2001). Of the 178 fragments of stylus tablets examined, 149 were of silver fir, a small number of oak, cedar, yew, ash, box, juniper and larch. The same is generally true of most other writing tablets from Britain (RIB, II-4, p. 11). The most notable exception is Stonea, where stylus tablets were of ash.

50. It is unclear for example how the surface of the tablet was prepared for writing, although perhaps some sort of beeswax size was used (Bowman, Thomas, a paraitre). to stiff clumsiness, although quality cannot be taken as evidence for the degree of the writer's literacy (for example the poor writing of the elegant closing formula in the birthday invitation, Tab. Vindol., II, 291). The literary 'Latinity' of some texts (e.g. Tab. Vindol., II, 225) indicates advanced education in the traditional Roman curriculum, while other evidence, for example old-fashioned elements in orthography, may attest scribal training in the army. The possible writing exercises may be evidence for learning of Latin at Vindolanda itself (e.g. Tab. Vindol., II, 118-120). Some tablets, in particular those whose content suggests they were produced by civilian traders (e.g. Tab. Vindol., II, 343), are more marked by non-standard syntax and vocabulary, but in general the standard of Latin is good 51 . Although our view is partial, the large number and diversity of individuals producing and reading documents in this military community emerge clearly, along with common subscription to conventions of script and format.

3. The tablets show (and are the residue of) the management of resources and men at a daily level through documents. Documents tracked and organized large and small scale transactions related to the acquisition and redistribution of supplies. Likewise the whereabouts and condition of troops are monitored through them. The processing and exchange of information through documents must have been integral to strategies of control and arranging military dispositions. Alongside and intertwined with military organization was the role of documents in establishing and sustaining social relationships by officers, soldiers and their dependants. Even if not all the inhabitants of the fort could read or write, documents were not only familiar but also integral to the organization of daily life.

The origin of some of the Vindolanda tablets from other garrisons, as well as the discovery of writing tablets in other forts (e.g. Carlisle and Caerleon), suggests the existence of equivalent literacies in and around other British garrisons. Parallels in script, format and layout with Latin military documents found in Egypt suggest that this documentary culture could be widely typical of the army at this time. It is, however, difficult to derive implications for the general literacy of provincial communities. The tablets demonstrate the degree to which the literacy of individuals of provincial origin, in this case from northern Gaul, could be modified, but this must in large part be a specific product of service in the army. We might anticipate an expanded use of documents outside the army in communities which dealt with soldiers on a daily basis, for example the inhabitants of vici adjacent to forts and traders supplying garrisons, the latter perhaps attested in the texts. Veterans returning home may also have had an impact in this regard. We may also exploit

51. The types and subject matter of documents to be published in Tab. Vindol. III are similar to those already published. The correspondence of Cerialis is the most numerous category of letters but ordinary soldiers (to judge from references to contubernales) and their families are also represented (Tab. Vindol. III, 641, 670), as well as women (Tab). Vindol. III, 635, 639, 661) and slaves (Tab. Vindol. III, 6.54). Document formats are similar to those already known (with some new rariants in letter and account layout) and the handwriting lies within the range already identified, with one striking exception, possibly from a later $2^{\text {nd }}$ century context (Tab. Vindol. III, 670). 
the evidence of further groups of writing tablets discovered elsewhere, most notably at Carlisle and London but also at other sites in small numbers. How the archaeological context of the Vindolanda tablets and of these other discoveries may extend our understanding of the uses of documents is now considered.

\section{ARCHAEOLOGY AND WRITING TABLETS}

At the most basic level, a review of the distribution of writing tablets, including instances with and without readable texts, has yet to be conducted. At the regional or provincial level, we may explore the general distribution of wooden tablets, to assess the extent to which they are circulating over time and space and in relation to different types of site. Previously wooden tablets have perhaps been thought to be too scarce to make such a survey worthwhile, but although not as numerous as inscriptions or graffiti, numbers are sufficient to validate a preliminary study. At the intra-site level, it may prove possible to associate documents with houses or areas of sites differentiated by function and/or socio-economic status, sometimes supported by documentary information that establishes individuals or households in archaeologically identified dwellings, especially in Roman Egypt. For example at Karanis, most papyri are located according to house and archaeological level (Van Minnen, 1994). Documents allow individuals and households to be associated with houses at different phases of use, although given the complexities both of the archaeological phasing and patterns of property occupancy, simple intersections between textual and archaeological evidence should not be expected. The distribution of documents can then be plotted in relation to these individuals or households. For example preliminary study shows literary papyri to be distributed in the houses of individuals of varied socio-economic status (Van Minnen, 1998, p. 131-136). At Herculaneum the association of stylus tablets with dwellings of different sizes and degrees of architectural elaboration combines with information from the texts to indicate the use of documents across a wide range of the social spectrum, although the connection between individuals mentioned in documents and the findspots is controversial (Wallace-Hadrill, 1994, p. 175-182).

Detailed attention to archaeological context is potentially an invaluable complement to subject matter or palaeography in elucidating the links between documents. Indeed, according to Martin (1994), the archaeological record of the relationship between documents is the touchstone for the definition of an 'archive', in the more restricted sense of documents which have been deliberately collected and stored together. Such archives permit detailed attention to particular administrative, legal or financial procedures. Special, often 'catastrophic' circumstances usually explain their survival, such as the stylus tablets from Campanian cities (Marichal, 1992b; Wallace-Hadrill, 1994, p. 175; Rowe, 2001), the Babatha papyri in the 'Cave of Ietters' (Yadin, 1963, p. 225) or the Petra papyri (Koenen, 1996). Archives may also survive in abandonment contexts, for example at Dura Europos (Welles et al., 1959, p. 36) or Kellis (Hope, Bowen, 1999), although these instances are less clearcut and may represent documents 'weeded' from archives rather than those deliberately kept together. More often groups of documents derive from rubbish deposits. In such circumstances, it may be possible to use context information to assess the relationships between documents with a looser shared connection, 'archives' in the sense of 'a group of documents which are linked by virtue of having the same author, recipient or place of origin' (Bowman, Thomas, 1983, p. 51) (for this the term 'dossier' may be preferred). In particular archaeological evidence may be critical to establishing chronological relationships between documents where internal evidence does not exist. Where such relationships can be reliably demonstrated, the cumulative value of documents as historical evidence is potentially much greater than their individual significance. It may be possible to use documents grouped by archaeological phases as the basis for establishing a sequence of historical development. This is the approach taken by A. Birley to the Vindolanda tablets, but it can only be legitimate if study of site formation processes demonstrates that documents were created, in circulation and then deposited within the same discrete phase (see infra).

Close attention to context is also essential for the study of the 'documentary culture' of the Roman world, in particular the treatment of documents when the immediate circumstances of their creation no longer pertained, in other words the archiving procedures of public and private administration (Posner, 1972). The similarity of certain types of documents between the Roman and modern world may mislead us into over-bureaucratising Roman practice and assuming that 'noncurrent' documents were stored with a view to efficient retrieval. The symbolism of producing and storing documents may have been more important that the maintenance of ordered archives (Purcell, 1986). Certain buildings can be identified as the probable home for archives of public or military documents, for example in town basilicas or in the fort principia, although documents have rarely been found in association with these buildings. The Bu Njem ostraka, mostly from the fort principia, represent one exception. Although found in rubbish deposits, their distribution provided evidence for the location of administrative responsibilities in the principia (Marichal, 1992a, p. 10-11). The examples cited above indicate the existence of 'private' archives. Some are from houses, for example stylus tablets from baskets and wooden boxes found in the upper storeys of buildings at Herculaneum and to a lesser extent Pompeii, or papyri from potential abandonment deposits at house 3 in Kellis, associated with broken vessels in which they had perhaps been stored. The $6^{\text {th }}$ century AD papyri from Petra, excavated in a church storeroom, relate to the property holdings of Theodore, a deacon, probably of the church in which the documents were found. The existence of such 'archives' does not indicate how they were used, but at least signals a contemporary value put on such collections and the potential for retrieval of documents.

The symbolic connotations lent by the depositional environment also deserve examination. For curse tablets, for example, deposition in spring or tomb is critical to the working of the curse (Tomlin, 1988). Such connotations deserve consideration in relation to other, 'secular' document types. For instance the agreements embodied in early medieval charters were lent 
authority by the placing of that document in church treasuries: indeed, here the act of deposition may have been more important in the creation of the agreement than allowing for the possibility of future reference (Clanchy, 1993, p. 156-157).

\section{PROBLEMS OF ARCHAEOLOGICAL EVIDENCE}

Consideration of the stages that intervene between the deposition of documents and their publication is critical to a study of archaeological context, including the processes of deposition and preservation as well as recognition, recovery and recording by archaeologists. In studying context we only study the place within which a document was finally deposited, but the document may have circulated widely before deposition and the information in the text may relate to a different time and/or place. Some archives of documents were accumulated over several decades (e.g. Alburnus Maior [132 and 160s], Bar Kokhba [94 and 132s], the Iucundus documents from Pompeii [30s to $70 \mathrm{~s} A D])$. A tablet found in London refers to the purchase of woodland in Kent (Tomlin, 1996), while stylus tablets found in Herculaneum had been enacted at other Campanian cities (Rowe, 2001, p. 235). Letters excavated at Vindolanda had been received at other places and brought to the fort (Bowman, Thomas, 1994, p. 43-44).

Documents preserved by 'catastrophe' (see supra) potentially give us a greater insight into the use of documents prior to their discard. However most of the ancient documents excavated by archaeologists were discarded as rubbish, for cxample in abandoned rooms or in streets, as at Mons Claudianus (Bingen, 1996) or on larger communal rubbish dumps, for example the Schutthügel, the vast rubbish deposit outside the northern fortress walls at Vindonissa (Speidel, 1996). Deposition as rubbish is likely to obscure relationships between documents, especially when the primary context of discard is further disturbed. For example some ostraka from Mons Claudianus were excavated in make-up deposits to level for building. In rubbish contexts however, relationships may survive, for example in the remnants of bonfires at Vindolanda or the individual deposits of rubbish within the dumps at Mons Claudianus.

Wooden tablets and papyri are of course only preserved in exceptional environmental conditions. In north-west Europe wooden tablets will only survive in contexts where anaerobic conditions have applied since their deposition, favouring deeply stratified urban or military sites. On rural sites such conditions are likely to apply only in deeper pit and well contexts.

Turning to problems arising during excavation, at the most basic level, documents have not always been identified as such. Although small numbers of ink tablets had been excavated prior to the discoveries of the early 1970s at Vindolanda, the significance of the document type was not appreciated and other examples had almost certainly been missed. The lack of contextual information is often a further hindrance. For groups of documents discovered up to the early $20^{\text {th }}$ century, especially papyri, contextual information is poor or absent, although it may be retrospectively possible to restore some connections. In certain cases however, for example Karanis, the contextual

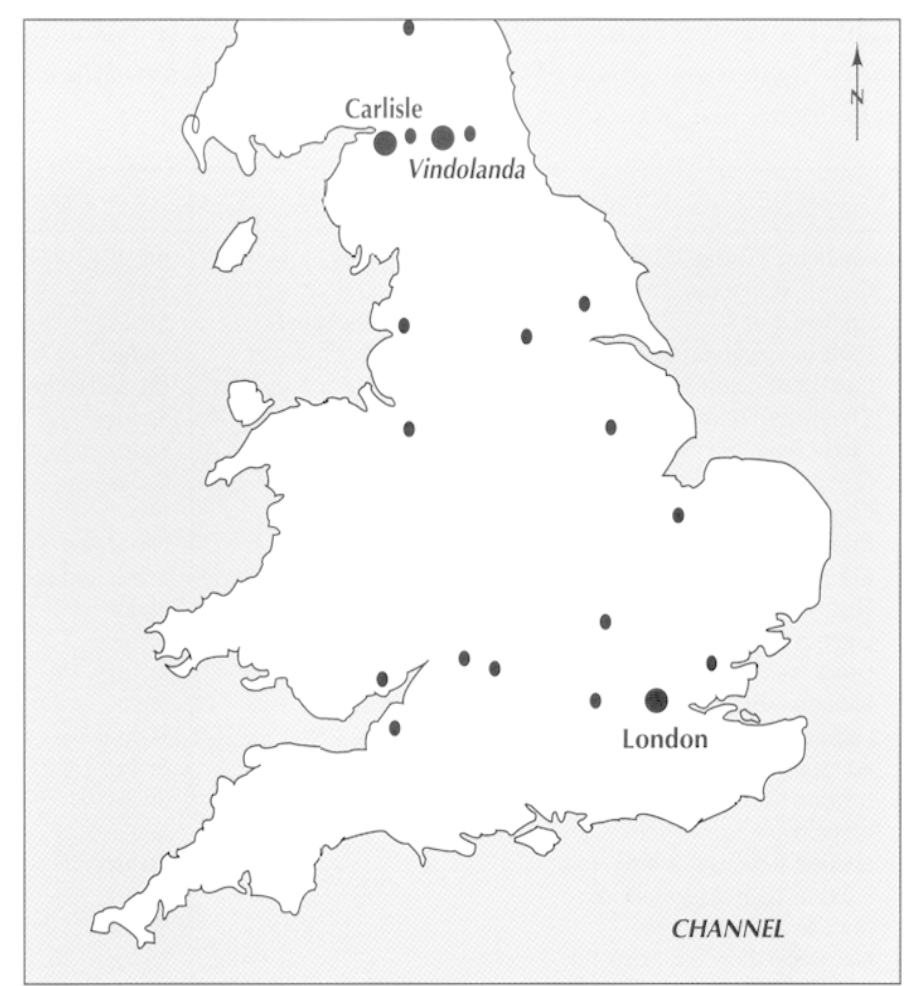

Fig. 36 - Plot of settlements on which wooden writing tablets are known to have been found in Britain. Small circles signify groups of $1-5$ tablets, large circles > 5 (only London, Carlisle and Vindolanda).

information recorded during excavation has not yet been fully exploited (Van Minnen, 1994).

In order to elucidate the depositional relationships between documents, the case for high-resolution recording of the location of each individual document is unanswerable. Recording by 'room' or even feature will usually be insufficient for such an exercise. At Kellis for example, recording to individual context allows more confidence in distinguishing documents relating to the occupation or abandonment of a house from those subsequently deposited (Hope, Bowen, 1999). Recording within context by 'papyrus group' (i.e. groups of papyri and fragments closely associated in space) at Kellis maintains a record of the association of documents, although it complicates the documentation of joins between individual fragments in different papyrus groups. It should perhaps be combined with the high-resolution three-dimensional recording of each fragment. Finally the scparate publication of documents and archaeological site means that details of context cannot always be exploited.

\section{THE SURVEY}

Wooden writing tablets have been found in archaeological deposits on nineteen settlements (fig. 36 and tabl. I). The predominance of military installations accounts for the concentration of findspots in northern Britain (tabl. II), although rural sites are also well-represented. In terms of numbers of tablets, finds from Vindolanda (1,000+ tablets) and to a lesser extent 
Tabl. I - Wooden writing tablets from Britain, organized by alphabetical list of settlemenis. This list provides the most recent references for all the individual and groups of documents referred to in the text. Please note that the lists for London and Carlisle are incomplete. A full list with concordance will be published in RIB, IV.

\begin{tabular}{|c|c|c|}
\hline SITE & TYPE & REFERENCES \\
\hline $\begin{array}{l}\text { Caerleon (Gwent, Wales) } \\
\text { Carlisle (Cumbria) Annetwell Street } \\
\text { Carlisle (Cumbria), Tullie House extension, Abbey Street } \\
\text { Carlisle (Cumbria) Castle Street } \\
\text { Castleford (West Yorkshire) } \\
\text { Chelmsford (Essex) } \\
\text { Chew Stoke (Somerset) } \\
\text { Cirencester (Gloucestershire) } \\
\text { Claydon Pike (Gloucestershire) } \\
\text { Cookham (Berkshire) } \\
\text { Corbridge (Northumberland) } \\
\text { High House (Cumbria) } \\
\text { Lincoln (Lincolnshire) } \\
\text { London - Walbrook / Bucklersbury } \\
\text { London - Queen Street / Queen Victoria Street } \\
\text { London Angel Court (Walbrook) } \\
\text { London Throgmorton Street (Walbrook) } \\
\text { London Cheapside Baths } \\
\text { London 1-7 Saint Thomas Street, Southwark } \\
\text { London Billingsgate buildings } \\
\text { London, Saint Magnus House } \\
\text { Middlewich (Cheshire) } \\
\text { Newstead (Borders, Scotland) } \\
\text { Ribchester (Lancashire) } \\
\text { Shiptonthorpe (East Yorkshire) } \\
\text { Stonea (Cambridgeshire) } \\
\text { Vindolanda (Northumberland) } \\
\text { Wavendon Gate (Buckinghamshire) }\end{array}$ & $\begin{array}{l}\text { Ink } \\
\text { Ink } \\
\text { Stylus } \\
\text { Stylus } \\
\text { Ink and stylus } \\
\text { Stylus } \\
\text { Stylus } \\
\text { Stylus } \\
\text { Ink } \\
\text { Not stated } \\
\text { Stylus and papyrus } \\
\text { Stylus } \\
\text { Stylus } \\
\text { Stylus } \\
\text { Stylus } \\
\text { Stylus } \\
\text { Stylus } \\
\text { Stylus } \\
\text { Stylus } \\
\text { Stylus } \\
\text { Stylus } \\
\text { Stylus } \\
\text { Stylus } \\
\text { Stylus } \\
\text { Stylus } \\
\text { Stylus } \\
\text { Ink and stylus } \\
\text { Stylus }\end{array}$ & $\begin{array}{l}\text { Hassall, Tomlin, 1986, p. 450-452; Zienkiewicz, 1993, p. } 121 . \\
\text { Tomlin, 1998. } \\
\text { Tomlin, 1991, p. 300-301, n 25; Caruana, 1992. } \\
\text { McCarthy, 1991; Padley, Winterbottom, 1991; RIB, II-4, 2443.3-6, 10, } 12 . \\
\text { Morris, 1998, p. 335-337. } \\
\text { pers. comm. Nick Wickenden, Chelmsford Museums. } \\
\text { RIB, II-4, 2443.13; Rahtz, 1977, p. 63, 369. } \\
\text { pers. comm. Emma Harrison, Cotswold Archaeological Trust. } \\
\text { Grew, 1980, p. 384; Bowman, Thomas, 1983, p. 35. } \\
\text { pers. comm. Reading Museum Service. } \\
\text { Allason-Jones, Bishop, 1988. } \\
\text { Simpson, Richmond, 1935, p. 227. } \\
\text { Jones, 1999. } \\
\text { RIB, II-4, 2443.2, 7, 8, 11, 15, 16, 20, 21. } \\
\text { RIB, II-4, 2443.9. } \\
\text { RIB, II-4, 2443.22. } \\
\text { RIB, II-4, 2443.19; II-8, 2504.29; Tomlin, 1996. } \\
\text { Marsden, 1976; RIB, II-4, 2443.18. } \\
\text { Chapman, 1978; RIB, II-4, 2443.1. } \\
\text { Chapman, 1980. } \\
\text { Chapman, Straker, 1986. } \\
\text { pers. comm. C. Constable, LP: Archaeology. } \\
\text { Curle, 1911, p. 308. } \\
\text { pers. comm. P. Tostevin, Ribchester Museum Trust. } \\
\text { Frere, 1992, p. 275. } \\
\text { Jackson, Potter, 1996, p. 546-547. } \\
\text { Birley et al., 1994; Bowman, Thomas, 1983, 1994, à paraitre. } \\
\text { Williams et al., 1995, p. 158, 264. }\end{array}$ \\
\hline
\end{tabular}

Tabl. II - Table of settlement types

from which writing tablets have been excavated.

\begin{tabular}{|l|l|l|l|}
\hline MILITARY & URBAN & SMALL TOWN & \multicolumn{1}{|c|}{ RURAL } \\
\hline Caerleon & (Carlisle) & Chelmsford & Chew Stoke \\
Carlisle & Cirencester & Middlewich & Claydon Pike \\
Castleford & Lincoln & & Cookham \\
Corbridge & London & & Shiptonthorpe \\
High House & & & Stonea \\
Newstead & & & Wavendon Gate \\
Ribchester & & & \\
Vindolanda & & & \\
\hline
\end{tabular}

London (200+ tablets) and Carlisle (150+ tablets) dwarf those elsewhere ${ }^{52}$. All the other settlements are represented by individual or small groups of finds, most comprising one or two and none exceeding five tablets or fragments of tablets. The concentration in London may be a product of the much more extensive investigation of waterlogged deposits than in other cities, although other reasons may also be advanced (see infra). Since preservation favours urban and military sites, the discovery of writing tablets on rural sites, including villas (Chew Stoke) and non-rilla sites (Wavendon Gate, Shiptonthorpe) may be more significant than the bald numbers suggest. Only at Vindolanda and Carlisle have many ink and stylus tablets been found. Stylus tablets comprise almost all the finds of individual and small

52. The estimates are imprecise since many documents from the larger sites remain unpublished. groups of tablets, although single finds of ink tablets have occurred (e.g. Caerleon, Lechlade, Castleford and London).

The number of $1^{\text {st }}$ and $2^{\text {nd }}$ century writing tablets is much greater than for the late Roman period, but this is merely a reflection of the predominance of Vindolanda, Carlisle and London in the sample. The Carlisle and Vindolanda groups date to the later decades of the $1^{\text {sts }}$ century $\mathrm{AD}$ and early $2^{\text {nd }}$ century. The 64 tablets from dated contexts in London are evenly spread across the $1^{\text {rst }}$ to $3^{\text {rd }}$ centuries AD (Elkins, 2001, p. 19-20). Individual or small groups of tablets elsewhere have been found in later contexts, including Chew Stoke, Wavendon Gate, Stonea and Lechlade. The numbers are too small to suggest that the early date of most military examples and later date of most rural examples are significant ${ }^{53}$.

\section{VINDOLANDA}

Vindolanda currently offers the greatest potential of any site in Britain for an analysis of documents in relation to context, since anaerobic conditions apply across the pre-Hadrianic levels. Most tablets derive from the phases during which the praetorium occupied the excavated area, in particular phase 3 (fig. 37). Most period 3 tablets were excavated among the remains of bonfires in the praetorium yard and near the south gate of the fort. Others were found in the rooms of the praeto-

53. Although later Roman tablets are fewer, Marichal's claim that there is no tablet dated later than the $2^{\text {nd }}$ century in the western empire camnot be upheld (Marichal, 1992b, p. 2). 


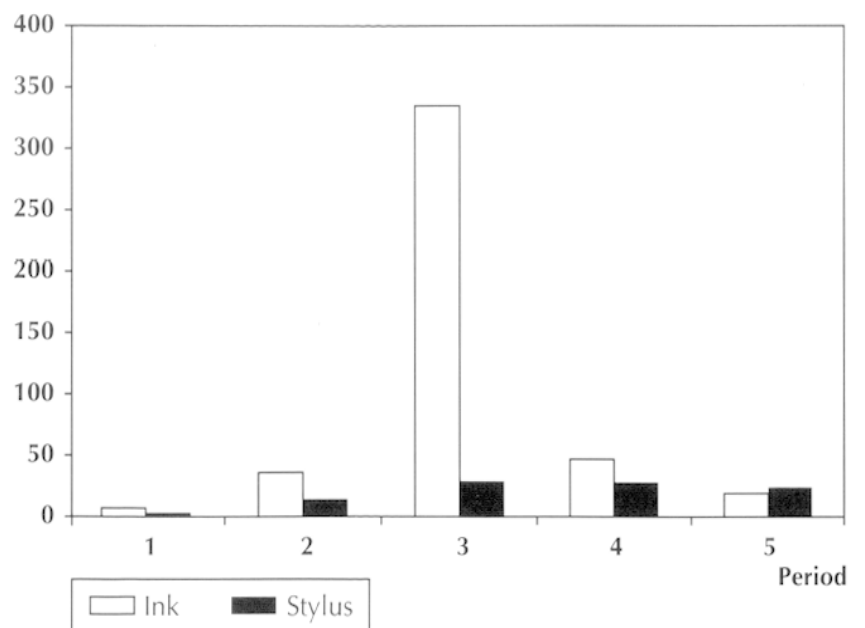

Fig. 37 - Numbers of ink writing tablets by period at Vindolanda: 1, $A D$ 85-c. 92, fort ditch; 2, AD 92-97, praetorium; 3, $A D$ 97-105 praetorium; 4, $A D$ 105-c. 120, barrack block, possibly centurion's or optio's quarters; 5, $A D$ c. 120-c. 130, fabrica (?).

rium, in the period 1 ditch that preceded it and in the rooms of the probable barrack block and workshop of periods 4 and 5 respectively that later occupied the site (the small excavated area and the poor survival of structures in periods 2, 4 and 5 hinders a definitive identification of the buildings). Stylus tablets were mostly found in rooms rather than in bonfire deposits and do not share the same bias to period $3^{54}$ (fig. 37 ).

Most tablets were not therefore found in the context in which they had been produced or stored, although proximity and subject matter indicate that most originated in the praetorium. Within the rooms of the different buildings some were found embedded in the compressed bracken and straw flooring material, suggested by the excavator to be the remnant of the flooring of the final year of occupation in each phase (Birley, 1994 , p. 13). If so, this 'laminate' preserves in situ remains of activity. Alternative formation processes must however be considered, for example rubbish dumping on the abandonment or demolition of buildings, the redeposition of material during levelling, either to flatten rubbish dumps, to raise the levels of areas prone to subsidence over the first fort ditch (Birley, 1994, p. 58), or through disturbance of earlier deposits.

The leather assemblage from the site illustrates the difficulty of distinguishing the relative importance of these depositional processes. Fragments of the same item, for example tent panels, shoes and horsegear were scattered across different parts of the site, suggesting the spreading of rubbish, perhaps for levelling up. On the other hand, some related pieces remained in close association, suggesting proximity to the context in which they had first been deposited (Van DrielMurray, 1993, p. 4, fig. 4 and 8).

The distribution of parts of individual tablets and of groups of documents also demonstrates the potential complexity of

54. M. Haran identified differences in the distribution of stylus and ink tablets excavated in the $1970 \mathrm{~s}$ and subsequent excavations have confirmed this difference (Haran, 1996, p. 220-221). Analysis is reserved for a future date. depositional pathways. The three fragments of Tab.Vindol., II, 298 for example were found in two different levels. Different tablets from the 'correspondence of Saecularis' (Tab.Vindol., II, 213-216) were found in contexts of different periods and laterally separated across the site ${ }^{5 \mathbf{3}}$.

A. Birley's period by period account of pre-Hadrianic Vindolanda depends on the assumption that the documents from archaeological deposits of the same period were also produced and in circulation in that period. On this basis, the subject matter of documents of each archaeological period can be closely associated, permitting a history of individuals and events at the site with a high chronological resolution (Birley $e t$ al., 1993 , p. 14; Birley, 2002). However given the role of different formation processes, it is dangerous to assume such a linkage.

These difficulties should not detract from more general points of interest. The wide distribution of tablets, in the praetorium, a barrack block and fabrica, complements the evidence of the texts for the use of documents by a significant proportion of the fort community. From the praetorium come documents connected both to the running of the household and the garrison, for example requests for leave, renuntia, and documents on the dispositions of personnel, although certain types of documents are missing, for example lists of regular supplies and disbursements or pridiana, (probably) annual reports on the personnel and dispositions of units (e.g. see the Carlisle tablets, Bu Njem ostraka [Marichal, 1992a] and military papyri [Fink, 1971, p. 180-182]). This association suggests the interconnectedness of unit and household administration (Bowman, 1994, p. 121-122).

\section{CARLISLE}

Over 150 stylus and ink writing tablets have been found in excavations since the 1970s on the Roman fort and town of Carlisle (I.uguvalium). The ink tablets are a mixture of accounts and letters; on the stylus tablets, so far, only letter addresses have been read. The majority of tablets have been found in contexts in and around the early Roman timber forts of the later $1^{\text {st }}$ and early to mid $2^{\text {nd }}$ century AD. The tablets are the earliest documented writing tablets known from Britain, dated by both archaeological context and the reference to the governor Agricola (Tab. Luguval., 44). There are localized differences in their distribution. Among the stylus tablets the proportion of leaves with a strip cut for witness seals is much higher inside the fort, perhaps a product of more legal and administrative documents in circulation here, but the numbers are small (McCarthy, 1991; Caruana, 1992, p. 69). In some cases the documents may relate closely to their context of use. Stylus tablets from phase 3 at Castle Street were found in and next to buildings $(1632,1633)$ that appeared to have served as stores for fodder and bedding. McCarthy (1991, p. 15-16) suggests that here 'official documents' were received and dispatched,

55. Tab. Vindol. III will provide further examples. Archacological relationships between tablets are difficult to document in detail since they are generally published only by room and period (Birley R., 1994). It is also not easy to relate the location of rooms of one period to those of preceding or following periods from the published plans. 
but there is no evidence that these documents (or letters) were official. Most tablets however were recovered from rubbish and demolition deposits, for example in the Tullie House Extension site and Annetwell Street. The highly fragmented state of the ink tablets and the lack of matches between stylus tablet leaves from the same context suggest that methods of disposal and reworking of rubbish deposits have significantly disrupted relationships between documents.

\section{LONDON}

Discoveries of writing tablets from London have been reported since at least the $1920 \mathrm{~s}$. The total number of tablets in the Museum of London (Elkins, 2001) and other collections plus documents from recent excavations is over 200, almost all stylus tablets from $1^{\text {rst }}$ to $3^{\text {rd }}$ century deposits. The significance for writing technology of a single ink tablet found in the $1950 \mathrm{~s}$ was not appreciated at the time (Turner, Skutsch, 1960). Individual documents, including private business transactions and legal documents, were already well-known but the total number is perhaps just as striking, especially in comparison to other towns.

Most instances derive from two general contexts. Waterlogged deposits from the port of the Roman city, for example material dumped behind revetments on the Thames river bank in London account for several of the recently excavated larger assemblages (e.g. Billingsgate buildings, Saint Magnus House). Waterlogged deposits associated with the Walbrook (the stream running south into the Thames that divided the Roman city) produced many tablets during construction work in the 1920s, 1930s and 1950s, as well as some in excavations of the 1980s and 1990s (e.g. n'1 Poultry, Throgmorton Street).

These concentrations might be a product of the original use or deposition of the tablets. H. Chapman and V. Straker (1986, p. 227) suggest for example that the Thames-side concentration reflected trading activity in this 'riparian commercial zone', but it is also likely to be due to more favourable preservation conditions. Other finds, for example at Cheapside Baths, in a Roman well at the junction of Queen Street and Queen Victoria Street and in Southwark ( $\mathrm{n}^{\text {os }}$ 1-7 Saint Thomas Street) suggest that their use was more widespread, as does the distribution of seal boxes (Holmes, 1995, p. 395).

Poor recording of earlier finds and the circumstances of deposition of more recent discoveries often frustrate closer attention to context. As at Carlisle, fuller assessment awaits the publication of several important sites. The association of wooden writing tablets with possible votive material has not hitherto been noticed. At Saint Thomas Street, Southwark, tablets were found in the fills of two timberlined pits, F28 and F29 (in F28 three leaves from a probable triptych were found in close association). The fill of both pits, especially F28, comprising whole and large fragments of pots, glass vessels and dog bones, suggests that they include a votive element (Dennis, 1978 , p. 305-306), although the presence of documents was not explained. An association with votive deposits may also apply to documents from the Walbrook, although the relative importance of votive deposition and rubbish dumping to channel the course of the stream in accounting for this material is not clear (Wilmott, 1991; Merrifield, 1993). Contextual information from better documented excavations, for example $n^{\circ} 1$ Poultry (Birch et al., 1997), will allow this question to be addressed more fully.

\section{OTHER SITES}

Many of the individual or small groups of writing tablets, almost always stylus tablets, from other sites derive from rubbish deposits in pits and dumps. A small number of writing tablets on rural sites were recovered from wells or shafts, the fills of which again comprised material reminiscent of votive deposits, including complete artefacts, animal and human body parts and whole bodies. For example at Shiptonthorpe two stylus tablets were found in the lower fill of a waterhole, the upper fill and surroundings of which included several animal and human infant burials. At Wavendon Gate, a waterhole fill (pit 835) included two stylus tablet fragments, complete pots, a spearhead and a miniature wooden wheel, perhaps recalling the symbol of the Gallic deity Taranis. Nearby was the setting of a post which, to judge by associated deposits, acted as a ritual focus. The association at Chew Stoke is less clear-cut but also suggestive, since with fragments of four or five stylus tablets in the well fill were nearly complete pots and two complete pewter jugs, building rubble and rubbish. The $2^{\text {nd }}$ century metalwork hoard from the fort at Corbridge has been interpreted as a deposit of mostly scrap metal (Allason-Jones, Bishop, 1988, p. 110), but a votive interpretation should not be discounted. At another fort, Newstead, several complete or near complete pots were found in the same pit (LXXVIII) as one of the writing tablets from the site.

\section{DISCUSSION}

Some tentative explanations for the patterns identified may be offered. The concentration of documents on military sites (or with military contexts in settlements, as at Carlisle) is consistent with the distribution of other document types (see supra) and supports the expectation of more intensive use of documents in the Roman army than in other types of provincial community. The concentration of documents in London also coincides with that of inscriptions on stone (for a RomanoBritish city, but the number is very modest in comparison to cities of comparable character Lyon or Cologne), graffiti (Evans, 1987 , p. 194) and curse tablets. That a city characterized by a cosmopolitan population, large-scale economic activity: copia negotiatorum et commeatuum maxime celebre (Tacitus, Annals, XIV, 33) and, from the late $1^{\text {sst }}$ century, the presence of provincial administration in the city should be associated with high levels of document use, also conforms to prior expectations concerning the distribution of literacy. Certain locations were favoured by much higher concentrations, in particular the Walbrook and the waterfront, but these may not be a reliable guide to the intensity of document use within the city. The major concentrations of writing tablets in neighbouring provinces come from cities of similar character, for example Cologne (Galsterer, 1983a) and Marseille (France, Hesnard, 1995). 
The presence of writing tablets (admittedly in small numbers) on a variety of rural sites is more surprising. Inscriptions on stone in a rural context are very scarce, but rural temples and settlements account for a high proportion of the 35 settlements on which lead curse tablets have been found (Ingemarck, 2001) and writing equipment has been found during the excavation of many rural settlements. We may tentatively suggest on this basis that the use of documents in a rural milieu in the north-west provinces has been significantly underestimated, even if it is unlikely to have ever approached the intensity of document use attested, for example, in rural Roman Egypt.

Depositional processes and a lack of information frustrate the study of the use and archiving of documents. All the documents from known contexts derived from rubbish deposits, sometimes rubbish that had been extensively reworked and redistributed. Nevertheless, some observations can be made. On military sites, documents have now been found in association not only with the praetorium (Vindolanda) but also barrack-blocks (Vindolanda and possibly Carlisle), a fabrica (Vindolanda) and tribune's house (Caerleon) as well as in fort annexes (Carlisle, Newstead). This supports the evidence of the Vindolanda texts for the widespread use of documents across the ranks. At Vindolanda documents related to household and unit administration were found in close association ${ }^{56}$. It might imply the close scrutiny of documentation by the prefect as a means of supervision of the unit. Alternatively, rooms in the praetorium might have served just as often as the tabularium for the location of clerical work, a more flexible designation of 'clerical' space within the fort than has hitherto been allowed. Too sharp a distinction should not perhaps be supposed between household and unit administration. This would be consistent with a generally close inter-relationship between the practice of Roman public or military administration and the management of private households and assets (Purcell, 1986). For provincials like Cerialis in command of military units, experience of military and household administration may have influenced the management of their own properties, perhaps also through slaves or freedmen.

At the micro-level one unexpected discovery was the recurring presence of documents in possible votive contexts on settlement sites. 'Votive' is used here as shorthand for contexts which are characterized by artefacts in unusual condition (often complete or near-complete) or in unusual combinations, differing from household rubbish. The interpretation of such 'structured deposits' is a long-standing concern of Iron Age archaeology (Hill, 1995) but a widespread sensitivity to their existence on Roman settlements is more recent (Fulford, 2001). They are perhaps the products of rituals associated with seasonal cycles and the rhythms of family life.

Two lines of interpretation may be suggested for the presence of wooden tablets in such contexts. They may have been used for ritual communication, more familiar from

56 . The contexts containing ink tablets from Carlisle also include a mixture of documents related to the running of the unit and letters, but most letters are too poorly preserved to determine their contents. The best preserved letter (Tab. Luguval. 16) is clearly related to military matters. inscriptions on stone and metal. Seal-boxes on temple sites have been argued to be indirect evidence of such a use (Derks, 1995; Bagnall-Smith, 1999). However where texts from possible 'structured deposits' have been read, they relate to business transactions (Chew Stoke, Walbrook). Perhaps the deposition of documents in rituals was part of the process of validating or annulling the agreements recorded in them.

$$
* *
$$

Conclusions drawn from this survey must be provisional. It is based on a small sample of evidence, heavily biased to a few sites and context evidence is often poor. The importance of further study of formation processes in relation to document assemblages, especially at Vindolanda, cannot be overstated. The article has aimed to be exploratory rather than exhaustive, but it has sought to indicate the potential of the study of contexts and provided a first characterization of the distribution of documents and their contexts against which future discoveries may be assessed.

The use of writing tablets emerges from this study in part as closely associated with the operation of Roman army and with communities, specifically of Roman London, which were hardly typical of the province. The archaeological evidence complemented the textual evidence to emphasize, for the early Roman periods, the wide distribution of the use of documents within those communities. The lack of suitable evidence did not allow detailed enquiry into administration and the archiving of documents, but the distribution of documents at Vindolanda underlined the impression from the texts of the close connection between 'official military' and 'private' affairs. Some individual finds of documents suggest that writing tablets could be associated with votive contexts, a previously unrecognized symbolic dimension to their deposition.

The survey also identified significant evidence from rural Roman Britain for the use of writing tablets. The evidence seems to demand some modification of the 'minimalist' view (Harris, 1989) of document use in the western provinces. The use of documents may be a product of the operations of Roman power but literacy should perhaps also be granted a higher profile among the cultural changes that accompanied 'becoming Roman' (Millett, 1990; Woolf, 1998). Did the use of documents become so embedded over time that we might imagine a Romano-British Babatha taking to the hills with a basket of writing tablets in times of social or political unrest? At present distribution patterns are too insecurely established to justify such spcculation, but we must be sensitive to their potential.

\section{Acknowledgements}

The work on which this paper is based was done whilst I was employed in an AHRB funded post-doctoral post in the Centre for the Study of Ancient Documents, Oxford University. I am grateful to the curators of museum collections and archaeological unit archives who responded to the survey on which the paper draws. Linda Elkins kindly allowed me to read her unpublished BA dissertation. Finally, I would like to thank Alan Bowman and Peter Haarer for their comments on drafts of this article, but they should not be held responsible for any of its errors. 